First Peoples Child \& Family Review

A Journal on Innovation and Best Practices in Aboriginal Child Welfare Administration,

\title{
Detoxifying the Child and Family Welfare System for Australian Indigenous Peoples: Self-determination, Rights and Culture as the Critical Tools
}

\section{Muriel Bamblett and Peter Lewis}

Volume 3, Number 3, 2007

URI: https://id.erudit.org/iderudit/1069396ar

DOI: https://doi.org/10.7202/1069396ar

\section{See table of contents}

\section{Publisher(s)}

First Nations Child and Family Caring Society of Canada

\section{ISSN}

1708-489X (print)

2293-6610 (digital)

\section{Explore this journal}

\section{Cite this article}

Bamblett, M. \& Lewis, P. (2007). Detoxifying the Child and Family Welfare System for Australian Indigenous Peoples: Self-determination, Rights and Culture as the Critical Tools. First Peoples Child \& Family Review, 3(3), 43-56. https://doi.org/10.7202/1069396ar

\section{Article abstract}

The toxic environment that is colonized Australia has broken many of the traditional circles of care for Indigenous children and created a service system which waits for Indigenous families to become dysfunctional before there is any response. The Victorian Aboriginal Child Care Agency (VACCA) encourages an approach to Indigenous children and families which is culturally respectful, culturally appropriate and framed according to the need to respect self-determination and human rights. VACCA has developed early childhood and family welfare policies which identify how cultural-strengthening works as a preventative measure to address risk factors for Indigenous children. With the ongoing reforms to Child and Family Welfare arising from the Children, Youth and Families Act, the Victoria State Government in Australia has an historic opportunity to lead the nation in creating an Indigenous-led child and family service system which focuses on issues of prevention and early intervention. The new Act prioritizes cultural and community connection in the best interest principles for Indigenous children, recognizes self-determination and requires generalist children's welfare services to be culturally competent. The only way to ensure that every Indigenous child is effectively cared for is by developing the capacity of Indigenous communities to look after their own by strengthening Indigenous organizations and agencies. It is Indigenous agencies who are best placed to deliver innovative programs which are culturally embedded and carefully targeted to restore the circles of care for Indigenous kids. Aculturally competent service system is what is needed to ensure better outcomes for Indigenous children.
This document is protected by copyright law. Use of the services of Érudit (including reproduction) is subject to its terms and conditions, which can be viewed online.

https://apropos.erudit.org/en/users/policy-on-use/ 


\section{Detoxifying the Child and Family Welfare System for Australian Indigenous Peoples: Self-determination, Rights and Culture as the Critical Tools}

\author{
Muriel Bamblett and Peter Lewis ${ }^{a}$ \\ a Victorian Aboriginal Child Care Agency, Australia
}

\section{Introduction}

Our approach in this paper is to provide an understanding of how the traditional circles of care for Indigenous children in Australia have been fractured historically by colonization and its ongoing impact through contemporary complex systems of disempowerment, disadvantage and cultural abuse.

We describe how the lives of Indigenous children can be put back together by restoring Indigenous circles of care through the creation of a culturally competent children and family service system which is focused on prevention and early intervention rather than just child protection.

The conceptual framework which the Victorian Aboriginal Child Care Agency (VACCA) promotes builds on a creative interplay of human rights principles and cultural respect. For the child and family service system such a framework means developing culturalbased programs and service standards out of which we create a new culturally competent service system for Indigenous children and families and creating a framework of trust and understanding between Indigenous, mainstream services and government.

The new Children, Youth and Families Act in the State of Victoria in Australia and its companion reform process is the first real attempt in Australia

Questions or correspondence concerning this article may be addressed to:

peterl@VACCA.ORG

\begin{abstract}
The toxic environment that is colonized Australia has broken many of the traditional circles of care for Indigenous children and created a service system which waits for Indigenous families to become dysfunctional before there is any response.

The Victorian Aboriginal Child Care Agency (VACCA) encourages an approach to Indigenous children and families which is culturally respectful, culturally appropriate and framed according to the need to respect self-determination and human rights. VACCA has developed early childhood and family welfare policies which identify how cultural-strengthening works as a preventative measure to address risk factors for Indigenous children.

With the ongoing reforms to Child and Family Welfare arising from the Children, Youth and Families Act, the Victoria State Government in Australia has an historic opportunity to lead the nation in creating an Indigenous-led child and family service system which focuses on issues of prevention and early intervention. The new Act prioritizes cultural and community connection in the best interest principles for Indigenous children, recognizes self-determination and requires generalist children's welfare services to be culturally competent.

The only way to ensure that every Indigenous child is effectively cared for is by developing the capacity of Indigenous communities to look after their own by strengthening Indigenous organizations and agencies. It is Indigenous agencies who are best placed to deliver innovative programs which are culturally embedded and carefully targeted to restore the circles of care for Indigenous kids. A culturally competent service system is what is needed to ensure better outcomes for Indigenous children.
\end{abstract}

at creating a culturally competent service system premised on the principle of self-determination for Indigenous communities. We believe that the Victorian experiment, if it is properly resourced, offers an historic opportunity to rebuild capacity for Indigenous families to once again 'look after their own'. Our hope is that the new policy environment 
in Victoria, in regards to Indigenous child and family welfare, will provide further opportunity to expand VACCA's culturally-embedded, family-strengthening programs and begin the complex process of detoxifying the social environment for Indigenous peoples in Australia.

\section{Colonized Australia as a Toxic Environment}

We cannot however go forward or talk about the future and discuss our actions or strategies without first looking back. For Indigenous people in Australia the process of colonization involved acts of disempowerment premised on, in many respects, Indigenous peoples being defined as part of the flora and fauna rather than as diverse communities with sophisticated systems of law, politics, economy, trade, ecology and culture. Indigenous economies were changed by land being cleared for the use of sheep and cattle and crops. Indigenous laws were ignored and the land treated as a terra nullius.

With disempowerment came disconnection as Indigenous communities were forced onto missions and reserves under the so-called protection of missionaries and overseers. Indigenous culture, spirituality and language was dismissed and discouraged. Diverse communities were forced to live together and their customs concerning kin and marriage were dismantled, creating confusion and brokenness. Finally Indigenous peoples were deemed a doomed race and their children were taken away under a racially defined understanding of 'best interests of the child.'

As a result of over 200 years of colonization, the Indigenous communities of Australia have been subject to a series of culturally inappropriate impositions and policy arrangements. These impositions have denied the reality of Indigenous communities, ignored their laws and customs and, ultimately, failed to recognize these communities as sovereign political and legal entities. At Federation no Indigenous person was consulted or involved, no recognition was given to Indigenous sovereignty or governance. The myth of terra nullius prevailed. The constitution's only mention of Indigenous people specifically excluded them from being counted as citizens and one of the early acts of Federal Parliament in 1902 denied Indigenous people voting rights. Indigenous communities have suffered from policies of 'protection', assimilation and integration.
In his history of child welfare in Australia, Robert Van Krieken, contends that social control theory has limited application in explaining general child welfare policy and development. He does note one critical exception, Indigenous families and the removal of their children. Indigenous child removal was clearly a policy premised on the need to control Australia's Indigenous peoples.

The whole issue of the 'Stolen Generations' has become a critical battleground in Australia's selfunderstanding. Since its release on May 26, 1997 the Bringing Them Home Report, which was a product of investigations and hearings into the historic practice of Indigenous child removal, has been pilloried as an insubstantial affront to Australian national pride or admired as an honest account of one of the most debilitating practices the colonizers has utilized to culturally dismember Indigenous people. Most churches and all state and territory governments have made their apology to the Stolen Generations. Only the Federal Government and the Federal Parliament have refused (although the Senate has passed its own apology resolution). The Report revealed for the first time in the broader public domain the reality and impact of government "forcible removal policies" on Indigenous peoples. Even the term "Stolen Generations" has become a matter of controversy. The term itself was coined by nonindigenous historian Peter Read who became aware of the large numbers of Indigenous children removed from their families and communities through much of the twentieth century. Through Indigenous childcare organizations and various Indigenous activist groups a campaign emerged in the 80 s to investigate this hidden phenomenon. Eventually the then Labor Government requested the Australian Human Rights and Equal Opportunity Commission to investigate the issue. Prime Minister Paul Keating's Redfern Speech in 1992 marked the first official acknowledgement of Indigenous child removal.

The context for this policy was Australia's official approach to Indigenous people, through its State and Commonwealth governments. Government policy changed from that of segregation through 'protection,' which forced the Indigenous population onto reserves or missions controlled by white officials, to that of assimilation in which Indigenous people (particularly so called 'half-casts') were to be subsumed into the 
general population. Child removal was one strategy in this assimilation policy.

It is estimated that tens of thousands of Indigenous children were removed from their families and raised in institutions or fostered-out to non-indigenous parents. One of the key ideas behind welfare is the idea of the 'best interests' of the client. Indigenous peoples in Australia have suffered greatly from a racially mythologized version of this idea. The story of the Stolen Generations is replete with examples of how their 'best interests' led to separation and alienation. When you live in a racist country - a racist presumption can lie behind any notion of best interests. In the case of the Stolen Generations the presumption is that non-indigenous families and, even more bizarrely, non-indigenous institutions can provide better care than Indigenous families.

Various state Aboriginal Protection Acts gave authority to Aborigines Protection Boards to care for Indigenous children, effectively denied their rights as parents and enabled removal of Indigenous children.

It made little difference what the family situation really was or how the children were cared for, because being Aboriginal was in itself reason to regard children as 'neglected.' Even on the rare occasions when officials did not regard Aboriginal culture with contempt and fear, the emphasis on marriage and having fixed housing and employment in definitions of 'neglect' was inherently biased towards seeing all Aboriginal life as neglectful.

The Bringing Them Home Report points out a critical meeting in 1937 which marks an official statement of the 'problem' from the point of view of the State Government Protectors. This meeting was the Canberra Conference of Commonwealth and State Aboriginal Authorities. The Conference believed that 'full-blood' Indigenous people were dying out. Incredibly the Conference saw no reason to slow this process and resolved that no government assistance was to go to missions which served full-bloods. For "natives of aboriginal origin, but not the full bloods", the Conference adopted a policy of "ultimate absorption... by the people of the Commonwealth."

While authorities asserted that, by removing them from their families and communities the lives of many Indigenous children would be improved the policy has led to issues of identity and a fracturing of families and Indigenous communities. So called 'best interest' has led to generations of despairing people.

The culturally abusive Stolen Generations episode was a specific racist and colonial practice which sought to 'whiten' and remove Indigenous peoples from the landscape of Australia. Its impact continues to disrupt Indigenous families today.

\section{Current Issues}

Child protection intervention in the lives of Indigenous community remains disproportionate in Australia. The reasons for this are complex and various. Annette Jackson, in her paper on child protection and the Indigenous community at the Eighth Australasian Conference on Child Abuse and Neglect suggests five interrelated factors:

- The Child Protection and Placement system may be overly interventionalist in relation to Indigenous children, due to limited understanding of cultural differences and the impact of history on Indigenous families.

- Fear, distrust and/or antipathy by Indigenous parents towards Child Protection authorities due to previous government policies therefore reducing access to less-interventionalist options which require cooperation.

- Indigenous disadvantage which creates greater risk of abuse and neglect.

- Absence of Indigenous specific universal and prevention services.

- The disproportionately large population of young people in Indigenous communities creating greater pressures for care.

American child psychologist, James Garbarino (1995) talks of socially toxic environments and their impacts on the raising of children. VACCA would argue that for Indigenous peoples, colonial/ dominant culture is such a toxic environment. Added to this, much of child protection practice is based on individualistic notions of child welfare and therefore at variance with Indigenous cultural perspectives. Even today culture is often blamed, overtly or covertly, for family dysfunction by some child protection services, ignoring the likelihood that it is the impacts of dominant, colonial culture which are creating the dysfunction. Dominant culture factors are most clearly present in considerations of 'the best interests of the child' which fail to acknowledge the importance of culture for both the child and the 
Indigenous community. As legal commentator, Philip Lynch suggests:

The dominant conceptualization of best interests ideology as applied by the courts tends to construct the best interests of First Nations and Aboriginal children as separate, distinct and abstracted from their constitutive familial, cultural and racial contexts.

A culturally-appropriate and non-discriminatory approach to Indigenous child protection necessitates that the best interests of the Indigenous child must take into account the Indigenous child's relationship to their culture and their community, particularly as it informs the child's sense of identity.

The aim of meeting the best interests of both the child and the community may be better achieved through the incorporation of a 'community's best interests' analysis into the 'child's best interests' analysis.

For Indigenous people 'neglect' is still one of the main reasons for notification and removal. We need to remind ourselves that for much of the 20th Century, as stated before, "being Aboriginal was in itself reason to regard children as 'neglected'." The matrix of the colonial/dominant culture continues to provide a racially discriminatory environment which both creates disadvantage and blames that disadvantage on Indigenous communities. Clearly neglect is primarily caused by economic and social poverty. Until rights issues are adequately addressed, Indigenous communities will continue to suffer systemic disadvantage.

When it comes to questions of abuse for Indigenous children what puts them most at risk is cultural abuse and a culturally incompetent service system which demonizes rather than treats the core problem. When the culture of a people is ignored, denigrated, or worse, intentionally attacked, it is cultural abuse. It is abuse because it strikes at the very identity and soul of the people it is aimed at; it attacks their sense of self-esteem, it attacks their connectedness to their family and community.

\section{Cultural Abuse Remains to this Day}

Unfortunately, the Indigenous child and family services system is still primarily focused on the tertiary end of the spectrum. It isn't good enough to have a service system which, in essence, tells Indigenous families to "come back later when your kids are being removed": that is, to be ambulance chasers waiting for families at the bottom of the cliff to fall off rather than catching them before they fall. We need to have the ability to intervene earlier without making Indigenous families fear once again that the welfare are coming to take their kids away.

The other area of complexity in Australia is how the relationship between Federal and State/Territory Governments tends to confuse the issue as to who is responsible for Indigenous child and family issues. Internationally, particularly in Canada, the United State and New Zealand, there is greater clarity as to which level of government is responsible for what. The source of clarity for those nations rests with their acknowledgement of self-determination.

\section{International comparisons}

The Bringing Them Home Report and more recently Chris Cunneen and Terri Libesmann in "A Review of International Models for Indigenous Child Protection" have observed some key international examples regarding how self-determination has impacted on Indigenous child welfare. In the United States, the Indian Child Welfare Act 1978 gives tribal courts exclusive jurisdiction in child welfare proceedings concerning Native American children who live on or have their permanent home on a reservation. State courts have joint jurisdiction with tribal courts over welfare matters which involve Native American children who do not have permanent residence on a reservation. State courts must transfer jurisdiction to tribal courts if the parents, the Native American custodian or the Tribe make a request unless one parent objects, the tribe has declined to handle the matter or the State court finds 'good cause' not to transfer the case (section 101 of the Act).

There are a number of cultural safeguards if a State court has jurisdiction over a welfare matter. The child's Tribe or American Native custodian must be notified and can intervene and participate at any point in the proceedings and all parties have a right to examine all reports and documents filed with the court (section 102). Voluntary relinquishment can only occur if the judge is satisfied that the Native American parent or custodian understands the terms of the agreement and must be in writing. Voluntary 
consent to foster care arrangements can be withdrawn at any time (section 103(a) and (b)).

An Indian Child Placement Principle is incorporated in section 105. An emergency removal of a child can occur where the child is in imminent physical danger (section 112). In these circumstances either the case must be referred expeditiously to the tribal court or the child must be returned home.

In Canada the Government recognizes Aboriginal autonomy and self-government and has made specific settlements and treaties with different Aboriginal First Nations. In 1995 the Canadian Government began negotiations with First Nations to define the exact powers to be transferred, determine what jurisdictions could be exercised and the nature of financial responsibilities. Child welfare and criminal justice issues have been included in this process. In 1989 the Department of Indian Affairs released a discussion document after a 3 year review. Since then, while provincial government child welfare systems remain in control of legislation, a number of First Nation communities have developed proposals and negotiated agreements transferring control. First Nation communities are continuing to develop culturally appropriate service models of their own.

Like Australia and the USA, Canada is a federation with the provinces taking responsibility for child welfare. Some First Nation organizations have called for national legislation to provide a framework to enable First Nation communities to take responsibility for child welfare.

In Aotearoa/New Zealand, the British invasion and subsequent wars between the Maori and the nonMaori led to the signing of the Treaty of Waitangi in 1840. While the Maori chiefs believed they had allowed for the presence of non-Maori, and not acceded sovereignty, the non-Maori assumed sovereignty as a consequence of the cross-cultural misunderstanding of the terms of the treaty. Despite this fundamental misunderstanding, the Treaty of Witangi has enabled Maoris to advocate for and, in certain situations, acted on rights of self-determination and Maori sovereignty. It has enabled constitutional appeals to seek justice in various areas of dispute between the Maori and the non-Maori.

In the 1980s and 1990s, Maori activist groups and Maori staff of the Department of Social Services contended that the Children and Young Persons Act
1974 (NZ) and the Department were racist in their approach to Maori children and demanded a level of Maori control over their own children. In response, the Department of Social Welfare commissioned a Committee to inquire and report on welfare service delivery to Maori communities. Arising from the Committee's report, the Children, Young Persons, and Their Families Act 1989 addressed child protection and juvenile justice with the aim of focusing on children's wellbeing in the context of their families, whanau (kin group), hapu (extended kin group with many whanau), iwi (descent group with many hapu) and family groups. Importantly, family group conferencing has been as an essential practical component of this approach to the child welfare needs of the Maori community. The key principles of this act include:

- Participation of family, whanau, hapu, and iwi in decisions affecting the child,

- An affirmation that intervention in a child's family life should be the minimum necessary to ensure their safety and protection,

- Consideration is given to the effect of intervention on the family, whanau, hapu, and iwi and

- That wherever practicable, the child should be placed with a member of the child's hapu or iwi or, if this is not possible, with a person who has the same tribal and/or cultural background and location.

Critical to this approach has been an acknowledgement of Maori self-determination although questions are often raised as to the adequacy of the resourcing of these principles and approaches.

\section{The VACCA Perspective}

It is clear that Indigenous agencies and communities are often caught between the politicking of the Federal and State/Territory levels of government. More often than not it is the Indigenous sector which gets the blame for failing to deliver. What is needed are clear Federal and State/Territory plans which compliment each other and recognize that selfdetermination is a critical organizing principle for effective Indigenous child welfare.

Self-determination was a key policy principle in Indigenous affairs in Australia from 1972 to 1996 and was the key consideration in the establishment of land rights legislation, the Keating Government's 
approach to native title and the founding of Aboriginal and Torres Strait Islander Commission. At both national and state/territory levels it needs to be said that effective self-determination has been limited, with only land rights legislation delivering any real measure of autonomy. In fact the process of being granted self-determination was experienced by many Indigenous communities as a process of confusion and abandonment. Trudgen recounts that, in the case of the Yolgnu people

\section{Some of the old men ... wept and said directly to the missionaries, 'Don't leave us. We will not survive without you against these other Balanda [white fellas]'}

What actually occurred in the case of the Yolgnu was that non-indigenous structures were placed upon the Yolgnu and traditional leadership structures were ignored, not to mention any actual engagement between the two legal systems to carry out the process of enabling self-determination in a cross-culturally appropriate way.

The formal nature of the relationship between Australian Governments and Indigenous peoples has remained undefined due to the lack of any treaty or treaties. The current Conservative Coalition Federal Government has abandoned self-determination as a policy principle.

The issue of self-determination was a key concern of the Bringing Them Home Report into the history of Indigenous child removal.

Clearly, the implementation of self-determination is important for juvenile justice, child welfare, adoption and family law matters. It is the principle grounding a right for Indigenous people to exercise control over matters directly affecting their children, families and communities. The Indigenous perspective on self-determination provides for the development of control over these areas of social life through processes which may involve some form of autonomy or self-government.

The Bringing Them Home Report recommends various measures to enable self-determination for Indigenous communities in the area of child welfare and protection. While its recommendations concerning draft national framework legislation have not been adopted by the Commonwealth Government nor agreed to by State/Territory Governments they do outline the critical issues at stake concerning the need for self-determination in the area of child welfare.

Before informed decisions can be made there needs to be proper negotiation between government and Indigenous communities and organizations relating to self-determination in juvenile justice, welfare and adoption matters. Communities must be in a position to make choices about what they see as suitable long-term solutions to particular issues.

In Australia, the Aboriginal Child Placement Principle influences the practice of Indigenous child protection. It is endorsed by the Secretariat of National Aboriginal and Islander Child Care and is accepted by State/Territory governments and, to varying degrees, incorporated into their child protection legislation.

The Aboriginal Child Placement Principle includes the following:

- Removal of any Aboriginal child must be a last resort.

- If, after consultation with community controlled Indigenous Welfare agency, removal of a child from its family is unavoidable then the authorities must have regard to the direction of the Indigenous agency.

- If such a removal is necessary, then the child must be placed within the extended family, or if this is not possible, the child may be placed within the Indigenous community, within close proximity to the child's natural family.

- If there is not an Aboriginal placement available, then in consultation with the relevant Indigenous agency the child may be placed with a nonindigenous family on the assurance that the child's culture, identity and contact with the Aboriginal Community are maintained.

At VACCA we promote the need to:

- Enable self-determination for Indigenous communities;

- Respect and embed culture into all aspects of service delivery;

- Encourage positive and mutually respectful engagement between Indigenous agencies and services and generalist services, and

- Provide services which are premised on holistic and strengths based Indigenous child and family principles. 
Human rights enables self-determination and selfdetermination enables Indigenous communities to have the capacity to take and action our responsibilities. For decades Indigenous leaders have emphasized rights not welfare. If Governments treat Indigenous people on the basis of self-determining rights as peoples instead of treating them as passive recipients of welfare as client communities, the debilitating effects of poverty can be overcome.

If we acknowledge that culture abuse is a significant problem then cultural-strengthening is the solution. Culture is central to identity. Culture defines who we are, how we think, how we communicate, what we value and what is important to us. We now know that fostering cultural identity is in the best interests of the child. This is not just true for Aboriginal and Torres Strait Islander people but for everyone. Modern child development theory has confirmed this.

Cultural identity is not just an add-on to approaches which focus on the best interests of the child. We would all agree that the safety of the child is paramount. No child should live in fear. No child should starve. No child should live in situations of neglect. No child should be abused. But if a child's identity is denied or denigrated, they are not being looked after.

Denying cultural identity is detrimental to their attachment needs, their emotional development, their education and their health. Every area of human development which defines the child's best interests has a cultural component. Your culture helps define HOW you attach, HOW you express emotion, HOW you learn and HOW you stay healthy.

In summary a culturally competent service system is one that:

- Focuses on the underlying socio-economic issues that lead to child neglect;

- Focuses on Indigenous children's right to culture;

- Views culture as a source of resilience;

- Responds holistically to child abuse and neglect recognizing that Aboriginal and Islander cultures view the whole child in the context of the whole family and the whole community;

- Focuses on child well being and early childhood development, including cultural well being; and
- Expands community based Early Childhood Service and Aboriginal and Torres Strait Islander Child and Family Welfare Agencies and Services

The ongoing development of Indigenous children's services that provide culturally appropriate programs that build on families strengths and capacities is a major goal for VACCA and much of our work is centred on supporting and resourcing these services to deliver programs and services focused on child abuse prevention, early intervention, family support and early childhood development.

\section{Capacity building for Indigenous Agencies and Workers}

It is a matter of justice and necessary for the development of just relationships between Indigenous and non-indigenous peoples for Governments to facilitate capacity building for Indigenous agencies and workers. Before invasion, Indigenous communities had the capacity to live fulfilling lives and look after their children. This capacity was diminished by the process of colonization which dispossessed and fragmented Indigenous communities. Economic capacity was removed by changing the environment to make it suitable for colonial economic exploitation. Societal capacity was diminished by forcing Indigenous communities to either live on reserves or the outskirts of colonial society. Capacity for looking after children was diminished in many instances by taking children away. It is therefore a matter of justice that Governments take the responsibility of working with Indigenous communities to develop economic and societal capacity in a dominant culture context.

VACCA therefore contends that it is the responsibility of governments in Australia to resource and work with Indigenous child welfare agencies to oversee and facilitate the development of child care capacity for Indigenous parents and communities. It is also governments' responsibility to enable the development of Indigenous child welfare agencies' engagement of the dominant culture through resourcing governance capacity and professional skill development. In the past, Indigenous child welfare agencies have been subject to ad-hoc funding of particular projects but not funding of infrastructure. Without long-term infrastructure development and support Indigenous agencies are often forced into shortterm strategies and unable to grow the organization 
so that it can be more strategic in its approach. Addressing capacity building issues are fundamental to any approach based on self-determination.

Indigenous child welfare agencies need to be able to provide a full range of services from prevention to intervention. They also require training to ensure culturally appropriate good governance and service provision. In terms of developing professional capacity there are a range of areas which need to be addressed through both short term and long term strategies. In the short term, funding for Indigenous workers, on-going professional training and periodic two-way secondment between Indigenous welfare agencies and Government human services departments is required. Capacity building of this nature is not only required in the area of child welfare but also in general organizational development such as finance and human resource management. In the long term, programs which encourage Indigenous participation in tertiary education for social work, community development, finance and human resource management are necessary to breakdown the dependence of Indigenous child welfare agencies on non-indigenous professionals and government departments.

It is apparent that the need to enhance accessibility and cultural appropriateness for services aiming to work with Aboriginal and Torres Strait Islander communities has been recognized by the government and non-government sectors, with some attempts being made to remedy the situation. Clearly, the education and training of Aboriginal and Torres Strait Islander workers and the encouragement of Indigenous management of community-based support services should remain priorities, if the issue of accessibility is to be addressed effectively.

What is required is capacity building to deliver Indigenous child and family welfare professional practice which embeds culture in service delivery and provides and understanding of issues such as the impacts of intergenerational trauma.

\section{Capacity building for non-indigenous Agen- cies and Workers}

Capacity building is a two way street. In order to address the needs of Indigenous communities and, in the case of VACCA, their children, the nonindigenous community and mainstream professionals and services, need to develop the capacity for engaging with Indigenous people in a culturally appropriate and non-racist manner.

There are two essential components in building the capacity of non-indigenous agencies and workers to engage Indigenous communities,

- Building cultural competence; and

- Building an awareness of the effects of dominant culture and how it privileges the non-indigenous as against the Indigenous.

Cultural competence has been defined as, a set of congruent behaviours, attitudes, and policies that come together in a system, agency, or among professionals that enable them to work effectively in cross-cultural situations.

A culturally competent program is one which, appreciates and values diversity; understands the cultural forces which impact the program; understands the dynamics which result from cultural differences; institutionalized cultural knowledge; and adapts its services to fit the cultural context of the clients it serves.

To create the conditions which may facilitate cultural competence for non-indigenous agencies and workers there are several understandings which need to be realized. Firstly it is important to increase the levels of participation of Indigenous agencies/workers and pay respect to their right to self-determination. Secondly it is important to recognise that there are over 300 Indigenous nations/peoples and therefore not to generalize. Thirdly there needs to be a recognition that the imposed dominant culture's alien values of individualism and materialism do not, in most cases culturally match with Indigenous cultures. In broad terms there are dichotomies of values between nonindigenous and Indigenous in the areas of

- Adversarial v. consensus decision making;

- Individual/presenting issue v. holistic based approaches to child welfare; and

- An individual/immediate family v. a cultural/communal understandings of the child as a person.

Understanding cultural competence is relatively easy when compared to becoming aware of the effects of dominant culture on the relationship between Indigenous and non-indigenous people. The former involves an awareness of cross-cultural interaction, the latter involves an awareness of how power effects both the oppressed and the privileged. 
Feminist scholar Peggy McIntosh contends that in mainstream society white people are privileged by the dominant culture. She suggest that there are at least 50 ways in which whites are unknowingly privileged by dominant culture. For example she says;

I can arrange to be in the company of my race most of the time;

If I need to move to rent or buy or if I need credit my skin colour will not be an obstruction to getting the property;

I can turn on the telly and see my race widely represented;

I can swear, get drunk, dress in second hand clothes, not answer letters without people saying how typical of my race;

I can do well without being called a credit to my race;

I am never asked to speak for all people of my race.

Further to this Peggy McIntosh suggests

I have come to see white privilege as an invisible package of unearned assets which I can count on cashing in each day, but about which I was 'meant' to remain oblivious. White privilege is like an invisible weightless knapsack of special provisions, maps, passports, codebooks, visas, clothes, tools and blank checks.

In the Australian context, entitlement for the non-indigenous is an unacknowledged space. Non-indigenous peoples contact with Indigenous people may help to deconstruct the 'white privilege' perception of the world to enable them to see the reality of this land. It is a way of acknowledging and limiting non-indigenous 'colonial blindness' which is created by the colonization process and maintained through dominant culture "habits of addiction. "Those who have been dispossessed by a social system are by definition less possessed by that system's illusions about itself."

In other words, non-indigenous agencies and workers need to 'listen the silenced into speech' and hear and see the stories and perceptions of the Indigenous community.

To this end, mutual understanding, collaboration and partnership building is essential. Through these partnership networks cross-cultural commonalities and differences can be explored and better understood.
The intention is to build capacity through developing networks and partnerships.

Much of Indigenous disadvantage occurs as a result of systemic racism and structures that exclude Indigenous governance, culture and reality. There have always been divisive views in the community in regard to the rights and 'place' of Indigenous people. For the general community, less fear of the unknown, more accurate information and greater understanding of issues that concern the lives and situation of Indigenous people. For the organizations involved, we hope to build a greater capacity to be inclusive or at least to maintain positive interactions with the Indigenous community.

The concept of working collaboratively and developing inter-organizational linkages with mainstream services will require significant attention. Forging partnerships must be understood in context of:

- Impaired trust;

- Indigenous people being reluctant to access mainstream services because of historical factors; and

- mainstream services lacking culturally appropriate skills and understanding.

The process of developing collaborative relationships takes time. In terms of interacting with non-indigenous peoples it is about converting the colonizers, the non-indigenous community. But it is essential that we pay heed to the warnings of Paulo Freire in reference to those of the dominant culture who seek to journey with the oppressed:
It happens ... that as they cease to be exploiters or indifferent spectators or simply the heirs of exploitation and move to the side of the exploited, they almost always bring with them the marks of their origin [of being oppressors]: their prejudices and their deformations, which include a lack of confidence in the people's ability to think, to want and to know. Then a false solidarity emerges; one based on charity, paternalism or the desire for control.

\section{Implications for VACCA}

VACCA's role as an Indigenous child welfare agency in the context of a dominant culture environment is critical as it seeks to represent the child 
welfare aspirations of the Indigenous community.

Its role in relation to the dominant culture requires VACCA to be an advocate for Indigenous cultural values, aspirations and right to self-determine to governments and the mainstream community. Given that it is the dominant culture's imposition of alien legal/social/economic structures and systems which has debilitated Indigenous capacity to self-determine and care for children, it is incumbent on the dominant culture to restore that capacity through appropriate resourcing and training. Governments need to acknowledge the reality of the past, particularly in relation to the Stolen Generations, and its on-going effects both in terms of the generational trauma it has caused and within its own colonially blind child protection approaches, engage Indigenous communities in seeking solutions to child welfare problems and provide adequate resources so that Indigenous child welfare agencies can address these issues.

VACCA also needs to be a bridge between the Indigenous and the non-indigenous communities in order to facilitate a less toxic environment for Indigenous children. This means promoting crosscultural understanding and encouraging mutual capacity building. For the Indigenous community, VACCA can facilitate strategies of survival to enable positive child development. For the non-indigenous community, VACCA can provide cross-cultural education and develop strategies and partnerships which build their cross-cultural competence and develop their capacity to engage Indigenous communities without being culturally inappropriate, dominant or racist.

As VACCA seeks to build its own capacity, it will need to seek assistance from governments and the non-indigenous community. From time to time this will require the employment of people based on merit and professional ability and not necessarily on the basis of their status Indigenous persons. However the aim should be that, through appropriate mentoring and training, the aim will be to encourage and enable the eventual employment of Indigenous staff in these areas.

Through a positive engagement with the dominant culture, which includes providing analysis and critique, VACCA is well positioned to serve the interests of Indigenous communities in Victoria and facilitate communities of care for its children.

\section{Some VACCA Examples}

The following are some examples of successful culturally embedded programs we have at VACCA.

We have designed a playgroup program which is based on culturally embedded early intervention principles. Our playgroups have been a great success as they

- Provide activities which promote healthy development and enrich the lives of Indigenous children;

- Strengthen identity and cultural awareness;

- Strengthen families by:

- connecting them to community;

- strengthening inter-generational links;

- providing parenting advice and support and

- linking children and families to universal services where required.

Because our playgroups are supported, workers are able to encourage families requiring greater support or crisis intervention to connect with and utilize the various programs provided by VACCA. In 2006 we had 83 families coming to 5 playgroups and have closely involved Indigenous Elders as volunteers for the service.

The Koorie FACES program is a family strengthening program developed by the Victorian Aboriginal Child Care Agency (VACCA) in partnership with the Victorian Aboriginal Community Controlled Health Organisation (VACCHO). The program aims to build confidence in parents and families of Indigenous children, with an emphasis on an increased understanding and knowledge of self, Indigenous culture and parenting practices and styles to build resilience against drug and alcohol misuse in children.

Koorie FACES focuses on the value and importance of Indigenous culture and Indigenous families; using a range of activities to ensure participants are involved in a fun and interactive learning environment. Indigenous leaning styles have guided the methodologies used throughout the program and include group discussions, story telling - particularly by Elders, roles plays, fun group activities which are highly visual and interactive and time to reflect on learning. 
The program is not about telling families how to parent their children but focuses on participation and drawing on the groups own knowledge and experiences. We have had great interest and great success, at least in terms of the responses of Indigenous participants, in the program.

In terms of research, the evaluation of the - so far only pilot program - has provided us with a body of evidence which has strengthened our resolve in implementing 'yarnin' styled parenting programs to assist in empowering our families. By focusing on culture and the strengths of our families, particularly in the context of the impact and ongoing nature of colonization, Koorie FACES both communicates messages about parenting and how culture is a strengthening tool for bringing up kids to be resilient.

\section{The Victorian Experiment}

So with our rights-based, culturally-embedded conceptual framework in mind - how are we to develop collaborations to develop a culturally competent service system?

In this context we want to focus on the recent reforms put in place by the Victorian Government particularly as a result of the new Victorian Children, Youth and Family Act.

This is a historic time, a new time, perhaps. For two centuries non-indigenous laws have sought to control Indigenous people, deny their humanity and assimilate them. The Children, Youth and Family Act is a different kind of law. This is a law that establishes the principle of Indigenous self-determination as the basis for the decision making process in relation to Indigenous children. This is a law which values Indigenous culture and does not demean it.

In the previous two centuries government policies said it was in Indigenous children's best interests for them to lose their culture, to assimilate, to be like others. The new law acknowledges up front that it is in the best interests of an Indigenous child for their culture and their connection to family, kin and community to be maintained and supported. Indigenous people have known that for over 400 centuries, now, Victoria has it in its child and family law.
The new Children, Youth and Families Act also

- Enables the Secretary of the Department of Human Services to transfer responsibility for managing Children' Court protection orders to the head of an approved Indigenous agency;

- Makes mandatory compliance with the Indigenous Child Placement Principle;

- Makes mandatory the preparation of cultural plans for Indigenous children in out-of-home care; and

- Makes cultural competence one of the criteria for performance standards which community sector organisations must meet to stay registered.

What VACCA is hoping for is that the reforms will lead to a culturally competent service system. We believe that such a system must be built on the following aims which have been described in detail above.

- Ensuring Indigenous self-determination;

- Capacity building and resourcing Indigenous agencies so that they have the right infrastructure to operationalize their services through appropriate program development, human and financial management processes and deliver universal and preventative services as well as enhanced tertiary services; and

- Ensure that government, generalist community services organizations and the child and family judicial system are culturally competent by developing protocols, partnerships and collaborations and cross-cultural training.

For members of the dominant culture it can be harder to see the role culture plays in day to day life. But for those in a minority culture, the dominant culture plays a more visible role. Understanding the effects of the dominant culture on the relationship between Indigenous and non-Indigenous people is not easy. However, fundamentally it's about understanding how power and privilege affect us all.

There is a power dynamic which is always present but seldom recognized.

There are cross-cultural issues where there are frequently misunderstandings.

There is a lack of acknowledgement how practice often has a cultural bias - we see culture as a positive for resilience and lack of acknowledgement of culture as a risk factor. 
Our hope is that with sound cross-cultural training and more importantly, sensitivity, these issues can be positively addressed.

As in any mature relationship, mutual respect and a positive attitude towards each other provides the best foundation. If generalist services believe that Indigenous people, culture and heritage make a positive contribution to the nation, and are not just 'problems' to solve, our relationships can deepen and be mutually beneficial. If we are to have a better relationship between our peoples we must begin with understanding and respect.

It's about creating a framework of trust and understanding between Indigenous and generalist services. It is a question of capacity building - for both Indigenous and non-indigenous people.

There are four aspects to this

- Firstly, non-indigenous people need to understand why Indigenous organizations are different - we are different because of our history and our role in the community.

- Secondly - recognizing both the importance of culture and the importance of capacity building the Indigenous sector.

- Thirdly, we know we cannot do it alone so it is critical, as part of capacity building our sector that we will need to establish partnerships which are about equity and cultural respect - and not just a way for non-Indigenous services to tick the Indigenous box

- And fourthly, we know that Indigenous families will, from time to time, require generalist services; so it is critical that generalist services - whether they are government or non-government, undergo capacity building to be culturally competent.

\section{Conclusion}

These are some clues as to how we build a culturally respectful and competent service system, re-create communities of care and embrace for our children. And this not only means helping Indigenous communities to embrace their children and families but also how mainstream culture can also be embracing of Indigenous peoples. One of our key projects at VACCA concerns building a Melbourne based Indigenous family centre called Moondani, which is the local Woiwurung word for 'embrace'. In many ways Moondani represents what we want for all Victorian Indigenous families and we are hoping that Moondani will be the first of many such family centres.

Embrace is a nurturing word and expresses the traditional Indigenous family value of how we embrace our children, families and communities and our embrace of the land. For our people all that we are comes from the embrace of the creator spirits for our people and our land. And through the land we feel that embrace which strengthens us and strengthens our culture. It is an embrace which we reciprocate through our family and community relationships. We need places of healing every where; for the land and our community.

So we would like to end with this picture that we use in Victoria - a vision of how we can build a respectful service system for Indigenous children and families.

The tree represents Indigenous cultures which stems from the land. Within the tree holds the children (yellow fruit) and the extended family (red fruit) and the community (the leaves). The black tracks that lead into the tree with the white tracks beside it represent VACCA and the Indigenous community walking alongside with Victorian government departments and generalist community service organizations. From each of the meeting places government departments and generalist agencies are able to learn more about Indigenous people and eventually appreciate and understand more about Indigenous cultures and Indigenous people are better enabled to navigate the dominant culture.

This picture is not just about compliance to a new system of care which respects Indigenous people and culture. It is about creating communities of embrace and reconciliation. It is a vision of the future for a social and cultural environment where Indigenous children are loved and valued for who they are and Indigenous children's culture and heritage is valued as a positive and vibrant part of the shared heritage of Indigenous and non-indigenous peoples as Australians.

At this stage it remains a dream - but one which we hope will, for Indigenous peoples, end the nightmare of colonization and, for non-indigenous people, provide a place of honour on the lands and waters of Australia. 


\section{References}

Aboriginal Child Placement Principle. (2002). Melbourne: Victorian Government Department of Human Services.

Anderson, Ian. (2003). Introduction: the Aboriginal critique of colonial knowing. In Michele Grossman (Ed.), Blacklines: Contemporary Critical Writing by Indigenous Australians (pp. 17-24). Melbourne: Melbourne University Press.

Ashford, B.E. \& Kreiner, G.E. (1999). "How can you do it?" Dirty work and the challenge of constructing a positive identity. Academy of Management Review, 24, 413-434.

Atkinson, Judy. (2004). Trauma Trails: Recreating Song Lines - The Transgenerational Effects of Trauma in Indigenous Australia, North Melbourne: Spinifex Press.

Bamblett, Muriel. And Lewis, Peter. (2006). "A Vision for Koorie Children and Families: Embedding Rights, Embedding Culture", Just Policy: A Journal of Australian Social Policy, Edition 41, September 2006, (pp. 42-46) VCOSS.

Behrendt, Larissa. (2003). Achieving Social Justice: Indigenous Rights and Australia's Future, Leichhardt, NSW: Federation Press.

Birch, Tony. (2003). 'Nothing has changed': the making and unmaking of Koori culture. In Michele Grossman (Ed.), Blacklines: Contemporary Critical Writing by Indigenous Australians (pp. 145158). Melbourne, Melbourne University Press.

Cadd, Muriel. (2001) "From Assimilation to Self-determination: issues and priorities for Aboriginal and Torres Strait Islander Children," Just policy, sound research \& joint action: selected papers from the 2000 ACOSS Congress, ACOSS Paper 111.

Carson, Bronwyn., Dunbar, Terry., Chenhall, Richard D. and Bailie, Ross. (Eds.), Social Determinants of Indigenous Health, Crows Nest, Australia: Allen and Unwin, 2007.

Cunneen, Chris. and Libesman, Terri. (2002). A Review of International Models for Indigenous Child Protection. Available at http://www.austlii. edu.au/au/other/IndigLRes/2002/1/.

Curthoys, Ann. (2000). Mythologies. In Richard Niles (ed.), The Australian Legend and its Dis- contents (pp. 11-41). St Lucia, QLD: University of Queensland Press.

Deane, William. Opening Address at the Indigenous Governance Conference, April 2002, Canberra, p. 3, available at http://www.reconciliation.org.au.

Dyer, Richard. (1997). White, London: Routledge.

Freire, Paulo. (1972). Pedagogy of the Oppressed, Middlesex: Penguin Books.

Garbarino, J. (1995). Raising Children in a Socially Toxic Environment, San Francisco: Jossey-Bass.

Gabarino, J. (1999). Lost Boys: Why Our Sons Turn Violent and How We Can Save Them, New York: Free Press.

Holt, Lillian. (2002). In John Rickard and Vince Ross (Eds.) Unfinished Business: Texts and addresses from the Unfinished Business Conference (pp. 123-131). Melbourne: Desbooks.

hooks, bell. (1995). Killing Rage: Ending Racism, Harmondsworth: Penguin.

Horton, David. (ed.), The Encyclopaedia of Aboriginal Australia, Vol. 2, Canberra: The Australian Institute of Aboriginal and Torres Strait Islander Studies, 1994.

Human Rights and Equal Opportunity Commission. (1997). Bringing Them Home: Inquiry into the Separation of Indigenous Children from their Families. Sydney: HREOC.

The International Resilience Project (2004) - http:// www.theresilienceproject.

Jackson, Annette in collaboration with Cadd, Muriel, Brickell, Melissa, Rogers, Gwen, and Harrison, Gill. (2001, November). Child Protection - Working more effectively with Aboriginal families: Ideas and Processes. Paper presented at the Eighth Australasian Conference on Child Abuse and Neglect.

Jonas, William. (2002, August). Recognizing Aboriginal Sovereignty - implications for the treaty process. Paper presented at ATSIC National Treaty Conference.

Kirby, L. \& Fraser, M. (1997). Risk and resilience in childhood. In Fraser, M. (Ed.), Risk and Resiliency in Childhood: An Ecological Perspective (pp. 10-33). Washington, DC: NASW Press. 
Krieken, Robert Van. (1992). Children and the State: Social control and the formation of Australian child welfare, Sydney: Allen and Unwin.

Libesman, Terri .(2004) Child Welfare approaches for Indigenous communities: International Perspectives, Child Abuse Prevention Issues No. 20, Autumn 2004, Australian Institute of Family Studies, Canberra,

Lynch, Philip. (2001). "Keeping Them Home: The best interests of Indigenous children and communities in Canada and Australia', Sydney Law Review, Vol. 23, 2001.

McIntosh, Peggy. (1989). White Privilege: Unmaking the Invisible Knapsack. Peace and Freedom, July-August.

Milroy, Helen. (2005). In Preface S.K. Zubrick, S.R. Silburn, D.M. Lawrence, F.G. Mitrou, R.B. Dalby, E.M. Blair, J. Griffin, H. Milroy, J.A. De Maio, A. Cox, J. Li, The Western Australian Aboriginal Child Health Survey, Vol. 2, Perth: Curtin University of Technology and Telethon Institute for Child Health Research.

Moreton-Robinson, Aileen. (2000). Takin' Up to the White Woman: Indigenous Women and Feminism, St. Lucia, QLD: University of Queensland Press.

Moreton-Robinson, Aileen. (2003). “Tiddas talkin' up to the white woman: when Huggins et al. took on Bell”. In Michele Grossman (Ed.), Blacklines: Contemporary Critical Writing by Indigenous Australians (pp. 66-80). Melbourne: Melbourne University Press.

Myers, Ched. (1994). Who Will Roll Away the Stone? Maryknoll, NY: Orbis Books.

O'Brien, Peter. and Bond, John. (2002). Are We Helping Them Home? Surveys of progress in the implementation of the Bringing Them Home recommendations 1997-2002 and the responses of Government and Opposition, Canberra: National Sorry Day Committee, Public Discussion Paper.

Reivich, K. \& Shatté, A. (2002). The Resilience Factor. New York: Broadway Books.

Scott, Dorothy. (2000). Building Communities that Strengthen Families: Elements of Effective Approaches, Australian Institute of Family Studies Seminar Paper, November 2000.
Steering Committee for the Review of Government Service Provision, Overcoming Indigenous Disadvantage: Key Indicators Overview 2007, Canberra: Productivity Commission, 2007.

Steering Committee for the Review of Government Service Provision, Overcoming Indigenous Disadvantage: Key Indicators 2007, Canberra: Productivity Commission, 2007.

Tomison, Adam. (2002). Are we meeting Family Needs in Australia, Keynote Address, Connecting Families and Communities: Family Services Australia Annual Conference, October 2002, Darwin,

Tong, Char and Cross, Terry. Cross Cultural Partnerships for Child Abuse Prevention with Native American Communities, Portland, Oregon: Northwest Indian Child Welfare Institute, 1991.

Trudgen, Richard. (2000). Why Warriors Lie Down and Die: Towards an understanding of why the Aboriginal people of Arnhem Land face the greatest crisis in health and education since European contact, Darwin: Aboriginal Resource and Development Services Inc.

Victorian Aboriginal Child Care Agency. (2006). Koorie FACES Program Evaluation, Melbourne: VACCA. 